\title{
STUDY OF PHYSICO-CHEMICAL PARAMETER OF DEEPANG LAKE IN POKHARA VALLEY, NEPAL
}

\author{
Shubhas C. Bastola \\ Department of Zoology \\ Janapriya Multiple Campus \\ scbastola@yahoo.com
}

\begin{abstract}
The present study on Physico-chemical Parameter of Deepang lake in Pokhara valley, Nepal was performed for six months from August 2009 to January 2010. The study included various physico-chemistry parameter like transparency, temperature, $\mathrm{PH}$, free carbondioxide, dissolve oxygen and total alkalinity. The maximum transparency $2.5 \mathrm{~m}$ was recorded in January and minimum $1.4 \mathrm{~m}$ in August. In other months the transparency were slightly changeable. The maximum temperature $25.6^{\circ} \mathrm{C}$ was recorded in August and minimum $17.7^{\circ} \mathrm{C}$ in January. The temperature gradually decreased. The PH values were found mostly alkaline and were generally between 6.7 and 7.5 during the investigation period. The highest PH 7.5 was recorded in January and lowest 6.7 in August. Dissolved oxygen value gradually increased from $6.4 \mathrm{mg} / \mathrm{l}$ in August to $8.7 \mathrm{mg} / \mathrm{l}$ in January. The concentration of free $\mathrm{CO} 2$ ranged between $1.8 \mathrm{mg} / \mathrm{l}$ and $5.6 \mathrm{mg} / \mathrm{l}$ during the investigation period. The maximum value was $5.6 \mathrm{mg} / \mathrm{l}$ in August and $1.8 \mathrm{mg} / \mathrm{l}$ in January. The maximum alkaline value $114 \mathrm{mg} / \mathrm{l}$ was recorded in January and minimum value $105 \mathrm{mg} / \mathrm{l}$ in August. All these Physicochemical parameter meet WHO Standard of Water Quality.
\end{abstract}

Keywords : Parameter, Phytoplankton, Macrozoobenthos, Limnology, Metrology.

\section{Introduction}

Water is one of the most significant natural resources. It is a single worldwide natural resources distributed in all land, sea and atmosphere and unified by the hydrological cycle. It is the most important factor in the life on an organism as it is the major constituent of the protoplasm, plant, animals, microorganisms and aquatic life, all need water for their existence. In plants all physiological process like respiration, photosynthesis, absorption of nutrients and other metabolic processes are influenced by the amount of water available. There is about 1.36 billion cubic $\mathrm{km}$ water in which 37.5 million cubic $\mathrm{km}$ is fresh water (Subramnyam 1986). Water covers about three fourth of the Earth's surface of the total water about $70 \%$ is in the sea and oceans which is unfit for human consumption and remaining 3 percent of water occurs as fresh water 90 
out of 3\% about 2 percent existing as ice in polar caps and permanent glaciers and only $1 \%$ is available as fresh water in rivers, lakes, stream, reservoir and underground water. The determination of depth, transparency, temperature, $\mathrm{pH}$, free carbondixode dissolve oxygen and total alkalinity were taken into account following the standard method APHA (1989), Boyd (1979) Trivedy and Goel (1986), Polythene bottles were used to collect the water sample. The objectives of this investigation is to analyze the physicchemical nature of the lake water.

\section{Materials and Methods}

In an aquatic environment the water quality and living organisms directly depend on physico-chemical parameter. The determination of depth, transparency, temperature, $\mathrm{pH}$, free carbondioxide, dissolved oxygen and total alkalinity were taken into account following the standard methods APHA (1989), Boyd (1979) Trivedy and Goel (1986), Polythene bottles were used to collect the water sample. The physico-chemical parameter were identified by using the methods mentioned below.

\section{Transparency}

The transparency of water was measured in the field by immersing a Secchi Disc of $20 \mathrm{~cm}$ diameter in water and observing it visuality. The mean of "Just disappearance and reappearance" of the disc under the water was calculated with the help of equation given below.

Secchi Disc light penetration $=\frac{\mathrm{A}+\mathrm{B}}{2}$
Where,

A $=$ Depth of which Disc disappeared

B $=$ Depth of which Secchi Disc reappeared

The extinction co-efficient was calculated by using the following formula

Where,

$$
\mathrm{K}=1.7 \mathrm{D}
$$

$\mathrm{K}=$ Extinction co-efficient

$\mathrm{D}=$ Secchi-Disc reading and

$1.7=$ constant factor

\section{Temperature}

The water temperature was recorded with the help of standard mercury thermometer (graduated) with a precision of $\pm 0.1^{\circ} \mathrm{C}$ ). The measurement was simply carried out by dipping the thermometer bulb directly upto water surface and the reading was taken down.

\section{Hydrogen ion concentration (PH)}

Hydrogen ion concentration $(\mathrm{PH})$ of water determines the acidity, alkalinity and neutrality of water. The $\mathrm{PH}$ of water sample was determined by using an electronic pocket $\mathrm{PH}$ meter (Hanna-Instrument)

\section{Dissolved oxygen (DO)}

For the determination of dissolved oxygen, winkler's method was used. For this, BOD bottle $(300 \mathrm{ml})$ was filled with water sample. During the placing of stopper on the bottle 
care was taken to avoid trapping air in the bottle. In BOD bottle, $2 \mathrm{ml}$ of maganous sulphate $\left(\mathrm{MnSO}_{4}\right)$ solution and $2 \mathrm{ml}$ of alkaline potassium iodide (KI) solution were added at the interval of few seconds, with the help of separate pipette after removing stopper. The stopper was placed carefully to exclude air bubbles and the solution was mixed thoroughly by inverting the bottle for a few minutes. After the precipitate had settled sufficiently than $2 \mathrm{ml}$ of conc. $\mathrm{H}_{2} \mathrm{SO}_{4}$ was added to it. The stopper was replaced back carefully and the bottle was inverted for several time until the dissolution of precipitate was completed. $100 \mathrm{ml}$ of this sample was taken in a conical flask and titrated against sodium thiosulphate solution $\mathrm{Na}_{2} \mathrm{~S}_{2} \mathrm{O}_{3}(0.025 \mathrm{~N})$ using starch as indicator until a light coffee brown colour was appeared. Three readings were noted and their mean was taken out to dissolved oxygen (DO) in $\mathrm{mg} / \mathrm{l}$ by using the formula.

$$
\begin{aligned}
& \text { Dissolved oxygen }(\mathrm{mg} / \mathrm{l})=\frac{\mathrm{ml} \times \mathrm{N} \text { of titrant } \times 8 \times 1000}{\frac{\mathrm{V}_{2} \mathrm{~V}_{1}-\mathrm{V}}{\mathrm{V}_{1}}} \\
& \text { Where, } \\
& \quad \mathrm{N}=\text { Normality } \\
& \mathrm{V}=\text { Volume of } \mathrm{MnSO}_{4} \text { and Potassium iodide used } \\
& \quad \mathrm{V}_{1}=\text { Volume of bottle after placing the stopper } \\
& \quad \mathrm{V}_{2}=\text { Volume of the part of the contents titrated }
\end{aligned}
$$

\section{Free Carbon Dioxide $\left(\mathrm{CO}_{2}\right)$}

Free carbondioxide was determined by the simple titrimetric method. $50 \mathrm{ml}$ of sample was taken in a conical flask and 2-3 drops of Phenolphthalein was added as indicator. If the sample does not become pink and remain colourless it indicates the presence of $\mathrm{CO}_{2}$ in the water sample. Immediately the sample was titrated against sodium hydroxide $(\mathrm{NaOH})$ solution $(0.05 \mathrm{~N})$ until a faint pink colour appeared at the end point. The amount of free $\mathrm{CO}_{2}$ is the volume of $\mathrm{NaOH}$ consumed. Three readings of burette were noted and mean was taken which later on calculated by using the following equation as $\mathrm{mg} / \mathrm{l}$.

Free carbondioxide $\left(\mathrm{CO}_{2}\right)=\frac{\mathrm{ml} \times \mathrm{N} \text { of } \mathrm{NaOH} \times 100044}{\mathrm{ml} \text { of sample }}$

Where, $\quad \mathrm{N}=$ Normality

\section{Total Alkalinity}

For total alkalinity, $100 \mathrm{ml}$ of water sample was taken in a conical flask and added two drops of phenolphthalein indicator. The resulting sample remained pink indicating the presence Phenolphthalein alkalinity. Then it was titrated with hydrochloric acid $(0.1 \mathrm{~N})$ until the pink colour just disappeared. Then 2 or 3 drops methyl orange indicator was added to the same sample and titrated with hydrochloric acid of same normality $(0.1$ $\mathrm{N})$ until the yellow colour changed to pink. The volume of total hydrochloric acid was noted. Three reading were taken to determine the mean. The following formula was used to convert total alkalinity later in $\mathrm{mg} / \mathrm{liter}$.

$\mathrm{PA}$ as $\mathrm{CaCO}_{3}, \mathrm{mg} / \mathrm{l}=\frac{\mathrm{A} \times \mathrm{N} \text { of titrant } \times 100050}{\mathrm{ml} \text { of sample }}$ 
$\mathrm{TA}$ as $\mathrm{CaCO}_{3}, \mathrm{mg} / \mathrm{l}=\frac{\mathrm{B} \times \mathrm{N} \text { of titrant } \times 100050}{\mathrm{ml} \text { of sample }}$

Where,
$\mathrm{A}=\mathrm{ml}$ of $\mathrm{HCl}$ used with only phenolphthalein indicator
$\mathrm{B}=\mathrm{ml}$ of $\mathrm{HCl}$ used with phenolphthalein and methyl orange
$\mathrm{PA}=$ phenolphthalein alkalinity
$\mathrm{TA}=$ total alkalinity

\section{Results and Discussion}

The results of physico-chemical analysis of water samples collected from Deepang lake during the study period.

Table 1: Physico-chemical parameter of Deepang lake during the study period

\begin{tabular}{|l|l|l|l|l|l|l|l|l|}
\hline S.N. & Parameters & Aug & Sep & Oct & Nov & Dec & Jan & Average \\
\hline 1. & Transparency $(\mathrm{m})$ & 1.4 & 1.6 & 1.9 & 2.0 & 2.3 & 2.5 & 1.9 \\
2. & Temperature $\left({ }^{\circ} \mathrm{C}\right)$ & 25 & 24.8 & 22 & 21.5 & 18 & 17.2 & 21.4 \\
3. & PH oxygen & 6.7 & 6.9 & 7.1 & 7.1 & 7.2 & 7.5 & 7.0 \\
4. & Dissolve & 6.8 & 7.1 & 7.3 & 7.5 & 8.7 & 7.3 \\
5. & $(\mathrm{mg} / \mathrm{l}) \quad$ Carbondioxide (mg/l) & 105 & 4.1 & 2.8 & 3.9 & 2.7 & 1.8 & 3.4 \\
6. & Alkalinity (mg/l) & & & 113 & 113 & 113 & 114 & 110.8 \\
\end{tabular}

\section{Transparency}

The transparency was found comparatively lower in August, September and October and higher in November, December and January. The transparency was highest in January $(2-5 \mathrm{~m})$ and lowest in August (1-2m). The increase values in November, December and January may be due to the growth of planktons during that period.

\section{Temperature}

The highest temperature recorded was $25^{\circ} \mathrm{C}$ which gradually declined to the lowest $17.2^{\circ} \mathrm{C}$ in January. The water temperature of the lake seems to be related with the atmospheric temperature. The water temperature largely influence the physical, chemical and biological factors of an aquatic ecosystem. An increase in temperature may lead to the increase in photosynthesis thereby changing the total biomass of aquatic macrophytes, periphytic algae and phytoplankton. The solubility of gases in water is also affected by temperature. The oxygen retaining capacity of water diminishes and biological oxygen demand increases with the rise in water temperature (Holden and Armstrong, 1980). 


\section{Dissolved oxygen}

The concentration of dissolve oxygen (DO) was found lowest $(6.5 \mathrm{mg} / \mathrm{l})$ in August which gradually increased to reach the highest value $8.7 \mathrm{mg} / \mathrm{l}$ in January. The concentration of Do below single is considered to be insufficient for the survivability of many aquatic organism (WHO 1996) and DO volume below $2.5 \mathrm{mg} / 1$ is lethal to the fish community (Oli, 1990). A low concentration of Do in an aquatic ecosystem indicates the organic pollution of water quality (Verma and Agrawal, 1989).

\section{Hydrogen-ion Concentration}

The hydrogen ion concentration $(\mathrm{PH})$ recorded were in the normal range. The lowest $\mathrm{PH}$ recorded 6.7 in August and gradually increased to reach 7.5 in January. The PH of water below 5 and above 11 has been described as toxic and unsuitable for various groups of aquatic fauna.

\section{Carbondioxide}

The free carbondioxide concentration was variable. The highest concentration 5.6 $\mathrm{mg} / \mathrm{l}$ in August and lowest $1.8 \mathrm{mg} / 1$ in January. $\mathrm{CO}_{2}$ is very soluble in water. The photosynthetic activity of planktons in an aquatic environment is considered as an important critical factor for the fluctuation of $\mathrm{CO}_{2}$ and $\mathrm{PH}$ level. Free $\mathrm{CO}_{2}$ of water from carbonic acid $\left(\mathrm{H}_{2} \mathrm{CO}_{3}\right)$ which dissociates into $\mathrm{H}^{+}$and $\mathrm{HCO}_{3}$ ions. This brings change in $\mathrm{PH}$ of water (Rutter, 1953). The highest concentration of $\mathrm{CO}_{2}$ may be produced by the decomposition of organic matter and respiratory activity of aquatic plant and animals which are the principal governing factors of $\mathrm{CO}_{2}$ fluctuations.

\section{Total alkalinity}

The total alkalinity of Deepang lake water were $105 \mathrm{mg} / \mathrm{l}$ and $114 \mathrm{mg} / \mathrm{l}$ in August and January. The maximum value $(114 \mathrm{mg} / \mathrm{l})$ was recorded in January and minimum value presence of total Alkalinity was mainly due to carbonate and bicarbonate ions. Although the carbonate alkalinity occurs only in the absence of cabondioxide and the $\mathrm{PH}$ greater than $8.3 \mathrm{mg} / \mathrm{l}$. In Deepang lake total alkalinity was mainly due to the presence of bicarbonates.

The physic chemical parameter in an aquatic medium exhibit as influencing limnoogical factors of the quality and quantity of the total biota and their life processor. The existing metrological condition and chemical properties largely regulated the physical properties largely regulated the physical properties of water in an aquatic system. The interaction of these creates favourable, or unfavourable circumstance or the growth and development of biotic component. Abundance, composition, diversity and distribution of macrozoobenthos are related to various physicochemical and biotic characteristic (Dutta and Molhotra, 1986)

The presence of suspended and dissolved organic and inorganic materials, phytoplanktons and turbidity of water diminishes the secchi disc transparency status is essentially a function of the reflection of ligh and restriction of the penetration of light in an aquatic environment (stepanek, 1959). The values of secchi disc transparency showed much fluctuation during the present study period. 
All above physico-chemical parameter meet WHO standard of water quality. Dissolve oxygen which is the most important parameter in lake ecosystem was found above the permitted level of $5 \mathrm{mg} / \mathrm{l}$ throughout the study period.

\section{Acknowledgement}

I am highly indebted to university Grant commission (UGC), Sanothimi, Bhaktapur for providing the research grant to perform the present work. I wish to express deepsense of gratitude to associate professor Kishor Kumar Pokharel Department of Zoology, Prithivi Narayan Campus, T.U. Pokhara for his kind guidance regular supervision, practical suggestion and constant encouragement throughout the study period. I am greatful to associate professor Prakash Jung Shah former Head of Department of Zoology P.N. Campus Pokhara for providing the laboratory facilities.

\section{Reference}

APHA, 1989, Standard method for examination of water sewage and industrial water. American public Health Association, New York, 1874 PP.

Boid, C.E. 1979. heater Duality in warm water fish ponds. Aubum unive. Agr. Expt. Sation, Crafttonaster Print, Opelixa Alabama, 359 PP.

Dutta, S.P.S. and Malhotra, Y.R. 1986: Seasonal variation in the macro zoobenthic fauna of gadigrah stream (Miran Sahib) Jamuna INDIA J. Ecol> 13(1): 138-145 PP.

Holden, G.C. Armstrong, D.E. 1980. Factors factors affecting phosphorous release fromintact lake sediment cores. Environ. Sci Technol 14, 79-87 PP

Oli, K.P. 1996. An environmental study of Nepal's Begnas and Rupa lake HMG/IUCN, Nepal.

Rutter, F. 1953 : Fundamental of limnology (Translat D.G. Frey and F.E. J. Fry). Torond Univ. Toronto Press, 6 pp.

Stepanek, M. 1959: Limnological study of the reserver sedlic near zeliv. IX. Transmission and transparency of water. Sci. Pap, Inst. Chem. Technical, Prague, Fac. Technol. Fuel water 3(p+z): 363-430 PP.

Subramanyam, H. 1986. Engineering Hydrology $2^{\text {nd }}$ edition, New Delhi, India, 1-3 PP.

Trivedy, R.K. and Goel, P.K. 1986. 1986 : chemical and biological methods for water pollution studies envim, pub, katad, India 25/PP.

Verma, P.S. and Agrawal, V.K. 1988 cell biology, Genetics, Evolution and Ecology S. Chand and Company (Pvt) Ltd. Ram Nagar. New Delhi- 110055

WHO, 1990 European standard for drinking water $3^{\text {rd }}$ Ed. Geneva. 